\title{
Penanaman Kaliandra Sebagai Kayu Energi dan Hijauan Makanan Ternak Pada Pertanaman Agroforestri Masyarakat Desa Gerbosari, Samigaluh Kulon Progo
}

\author{
Eko Prasetyo $^{1^{*}}$, Wiyono ${ }^{2}$, Puji Lestariं ${ }^{3}$, Rochmat Hidayat ${ }^{4}$, Silvi Nur Oktalina ${ }^{5}$, Agus \\ Ngadianto $^{6}$, Prasetyo Nugroho ${ }^{7}$ \\ 1,2,3,4,5,6,7,8 Program Studi Pengelolaan Hutan, Departemen Teknologi Hayati dan Veteriner, \\ Sekolah Vokasi, Universitas Gadjah Mada \\ *Email: eko.prasetyo@ugm.ac.id
}

\begin{abstract}
Abstrak
Tujuan pengabdian "Penanaman Kaliandra sebagai Kayu Energi dan Hijauan Makanan Ternak (HMT) pada Pertanaman Agroforestri Masyarakat Desa Gerbosari Samigaluh Kulon Progo" adalah untuk 1) memberikan tambahan pengetahuan pemanfaatan kaliandra selain HMT yaitu sebagai bahan baku sumber energi dan 2) mempraktekan teknik penanaman kaliandra pada sistem agroforestri di Desa Gerbosari. Cara ternak yang dikembangkan di Dusun Keceme adalah "cut and carry system" atau sistem merumput. Sistem merumput membuat petani harus menyediakan lahan untuk ditanami HMT baik berupa rumput atau daun-daun pohon. Sosialisasi dan diskusi dengan masyarakat menghasilkan kesepakatan yaitu program yang dijalankan tidak sebatas penanaman kaliandra, tetapi aspek pemanfaatan kaliandra sebagai kayu energi dan pengenalan wood pellet diperlukan oleh masyarakat Dusun Keceme. Metode pelaksanaan pengabdian melalui 4 tahap dalam satu kesatuan skema. Metode yang dilakukan adalah 1) sosialisasi program, 2) penyuluhan, 3) praktek penggunaan kompor wood pellet dan 4) penanaman. Program pengabdian mampu memberikan pemahaman awal kepada masyarakat Dusun Keceme mengenai manfaat kaliandra sebagai alternatif energi terbarukan yaitu dalam bentuk pellet kayu. Teknik penanaman agroforestri kaliandra sudah lama dipraktekkan masyarakat Dusun Keceme yaitu di tepi-tepi teras lahan.
\end{abstract}

Kata kunci: hijauan makanan ternak, kaliandara, penanaman, wood pellet

\begin{abstract}
The purposes of community service entitled "Kaliandra Planting as Energy Wood and Forage Livestock Feed on Agroforestry Crops Gerbosari Village Community Samigaluh Kulon Progo" are 1). To provide additional knowledge of Kaliandra (Calliandracallothyrsus) utilisation other than HMT that is as a raw material of energy source and 2). To practice the technique of Kaliandra planting on agroforestry system in Gerbosari Village. The way cattle developed in Dusun Keceme is "cut and carry system" or grazing system. Grazing systems make farmers provide land for HMT planting either in the form of grass or tree leaves. Public dissemination and discussion with the community resulted in an agreement that the program is not only Kaliandra planting, but the utilisation of Kaliandra as an energy wood and wood pellet introduction is needed by Keceme Hamlet community. Methods of implementation of community service are through 4 stages in one unity of scheme. The methods are 1) program dissemination, 2) counselling, 3) practice of using a wood pellet stove and 4) planting. The community service program can provide an initial understanding of the community of Keceme Hamlet about the benefits of Kaliandra as an alternative to renewable energy that is in the form of wood pellets. The technique of agroforestry cultivation of Kaliandra has long been practised by the people of Keceme Hamlet that is on the edge of the terrace of the land.
\end{abstract}

Keywords: forage, Kaliandra, planting, wood pellet 


\section{PENDAHULUAN}

Luasan hutan rakyat di Kulon Progo cenderung meningkat dari tahun ke tahun, data menunjukkan bahwa sejak tahun 20042013 luasan hutan rakyat mengalami peningkatan sampai dengan 930 ha. Data BPS tahun 2013, menunjukkan bahwa jenis jati memiliki produktivitas tertinggi yaitu mencapai $25.073 \mathrm{~m}^{3}$, sonokeling $4.028 \mathrm{~m}^{3}$, mahoni $6.309 \mathrm{~m}^{3}$, sengon $3.861 \mathrm{~m}^{3}$ dan lainnya $2.570 \mathrm{~m}^{3}$. Sebagian besar hutan rakyat di Kulon Progo menggunakan sistem agroforestri yaitu pencampuran jenis tanaman kehutanan dengan tanaman pertanian, herbal atau ternak. Kelebihan sistem agroforestri secara ekonomi adalah diversifikasi produk menyebabkan ketahanan terhadap fluktuasi harga, pengaturan hasil dari jenis yang multi product menyebabkan hasil yang berkesinambungan, dan investasi yang murah bagi petani.

Berdasarkan keadaan topografi (Tabel 1.), salah satu kecamatan yang memiliki ketinggian $500-1.000 \mathrm{~m}$ dpl adalah Kecamatan Samigaluh. Salah satu desa di Kecamatan Samigaluh yang potensial untuk dikembangkannya jenis kaliandra sebagai jenis MPTS yang berkontribusi dalam pengembangan alternatif energi dan sebagai Hijauan Makanan Ternak adalah Desa Gerbosari.

Tabel 1. Keadaan Topografi Kabupaten Kulon Progo

\begin{tabular}{|c|c|c|}
\hline Kelompok & Keadaan Topografi & Wilayah \\
\hline Bagian & Perbukitan Menoreh dengan & Girimulyo, Samigaluh, Kokap dan sebagian \\
\hline Utara & ketinggian $500-1.000 \mathrm{~m} \mathrm{dpl}$ & Nanggulan \\
\hline Bagian & Daerah perbukitan dengan & Kalibawang, Nanggulan, Girimulyo, sebagian \\
\hline Tengah & ketinggian $100-500 \mathrm{~m} \mathrm{dpl}$ & $\begin{array}{l}\text { Samigaluh, sebagian Pengasih, dan sebagian } \\
\text { Kokap }\end{array}$ \\
\hline $\begin{array}{l}\text { Bagian } \\
\text { Selatan }\end{array}$ & $\begin{array}{l}\text { Dataran rendah dengan } \\
\text { ketinggian sampai } 100 \mathrm{~m} \mathrm{dpl}\end{array}$ & $\begin{array}{l}\text { Temon, Wates, Panjatan, Galur, Lendah, dan } \\
\text { sebagian Pengasih }\end{array}$ \\
\hline
\end{tabular}

Sumber: BPS Kabupaten Kulon Progo, 2011

Desa Gerbosari adalah sebuah desa yang terletak di daerah pegunungan menoreh di Kabupaten Kulon Progo. Secara administrasi Desa Gerbosari dalam wilayah Kecamatan Samigaluh Kabupaten Kulon Progo. Luas wilayah Desa Gerbosari adalah 966,3 Ha. Desa Gerbosari terdiri dari 19 dukuh, yaitu Dukuh Sari Mulyo, Kemiriombo, Jeruk, Pengos A, Pengos B, Manggis, Ketaon, Ngroto, Clumprit, Jetis, Karang, Jati, Tlogo, Dukuh, Sumbo, Sendat, Kayu Gede, Menggermalang dan Keceme. Kondisi Geografis desa Gerbosari berada pada ketinggian rata-rata $740 \mathrm{~m}$ di atas permukaan laut dengan suhu rata-rata 23$34^{\circ} \mathrm{C}$. Topografi desa termasuk pada daerah dataran tinggi dan perbukitan.

Adapun batas-batas wilayah dari Desa Gerbosari adalah sebagai berikut:

Sebelah Utara : Propinsi Jawa Tengah
Sebelah Selatan : Desa Banjarsari, Kecamatan Samigaluh

Sebelah Timur : Desa Ngargosari, Kecamatan Samigaluh

Sebelah Barat : Desa Sidoharjo, Kecamatan Samigaluh

Pengembangan jenis Multipurpose Trees Spesies (MPTS) diperlukan untuk mendukung sektor peternakan dan energi di Desa Gerbosari. Salah satu jenis MPTS yang dapat diterapkan dengan sistem agroforestri terutama di daerah perbukitan adalah jenis kaliandra. Produksi biomassa kaliandra cukup tinggi terutama di areal dengan ketinggian $>800 \mathrm{~m}$, sehingga memungkinkan optimasi penggunaan lahan-lahan di daerah tinggi yang tidak datar termasuk di lereng-lereng bukit (Hendrati dan Hidayati, 2014). Pemanfaatan tanaman kaliandra oleh petani sebagai 
hijauan pakan ternak masih sangat rendah mengingat masih kurangnya informasi dan sosialisasi.

Selama ini pengelola hutan rakyat di sebagian besar wilayah Gerbosari, Samigaluh menggunakan sistem agroforestri. Banyak jenis ditanam pada lahan yang sama. Pencampuran dilakukan karena kebutuhan masyarakat terhadap berbagai hal dapat terpenuhi dari lahan yang dimiliki. Kebutuhan masyarakat pada lahan adalah antara lain untuk produksi kayu, produksi hijauan makanan ternak, produksi empon-empon/herbal dan produksi perkebunan semisal cengkeh. Pemanfaatan hasil agroforestri di Desa Gerbosari dapat ditingkatkan dengan variasi hasil panen. Selain untuk Hijauan Makanan Ternak, keuntungan menanam kaliandra untuk produksi kayu energi antara lain pemanenannya dengan cara memangkas cabang-cabangnya yang dapat dilakukan secara berulang sehingga tidak perlu menanam pohon yang baru setelah pemanenan (Hendrati dan Hidayati, 2014). Gagasan Teaching Industry oleh Sekolah
Vokasi Universitas Gadjah Mada di Kabupaten Kulon Progo antara lain mengenai produk olahan kayu. Program Pengabdian Masyarakat Tahun 2016 yang berjudul "Penanaman Kaliandra sebagai Kayu Energi dan Hijauan Makanan Ternak pada Pertanaman Agroforestri Masyarakat Desa Gerbosari Samigaluh Kulon Progo" diharapkan menjadi langkah awal dalam penyediaan bahan baku produk olahan kayu terutama untuk kebutuhan energi. Hal di atas melatarbelakangi perlu dilakukannya penyuluhan dan pemberian informasi kepada masyarakat Desa Gerbosari, Samigaluh Kulon Progo mengenai ragam manfaat kaliandra dan proses penanamannya dalam sistem agroforestri.

\section{METODE}

\section{Kerangka Pemecahan Masalah}

Langkah-langkah

pemecahan masalah dilakukan secara terstrukur agar tujuan pengabdian masyarakat dapat tercapat. Langkah pemecahan masalah dapat dilihat dalam bagan berikut ini.

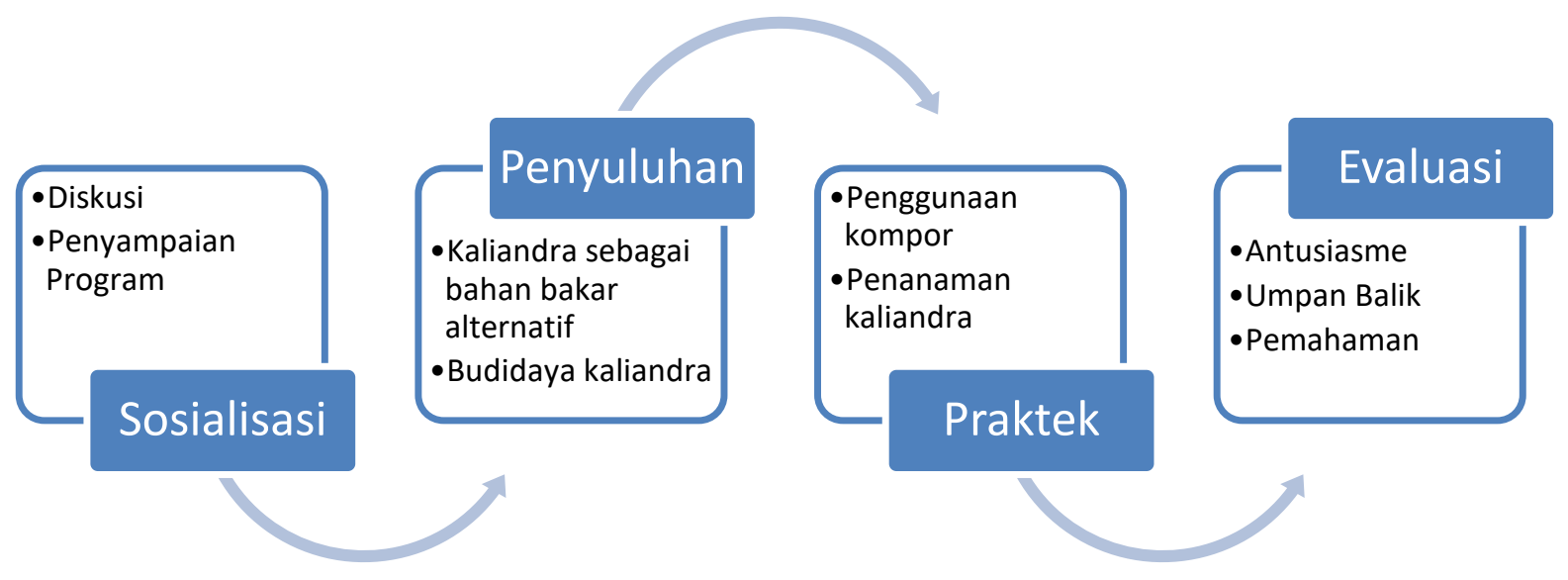

Gambar 1. Kerangka Pemecahan Masalah

Pengabdian Dusun Keceme

\section{Realisasi Pemecahan Masalah}

a) Sosialisasi program

Sosialisasi program dilakukan dengan melakukan diskusi dengan masyarakat Dusun Keceme Desa Gerbosari. Sosialisai dimaksudkan untuk menyeleraskan program pengabdian dengan kondisi masyarakat, potensi wilayah dan pengembangannya.

b) Penyuluhan

Penyuluhan dilakukan di Desa Gerbosari dengan menghadirkan narasumber terkait dengan tema budidaya kaliandra sebagai bahan baku energi. Tujuan kegiatan ini adalah untuk 
memberikan gambaran mengenai ragam manfaat tanaman kaliandra.

c) Studi Banding dan Praktek
Penggunaan Kompor Pellet
Rencana studi banding dilakukan dengan mengajak petani hutan rakyat ke (PT Solar Park Indonesia) di Wonosobo, Jawa Tengah. Perusahaan tersebut sudah beroperasi memroduksi sebanyak 48 ribu ton pada tahun 2009 dan meningkat menjadi 224 ribu ton pada tahun 2013, untuk memenuhi kebutuhan pasar pelet yang tinggi tersebut. Selama ini perusahaan masih menggantungkan pasokan dari sisa industri kayu dan setoran masyarakat, sehingga berbagai upaya dilakukan dengan mencari jenis tanaman yang cocok sebagai sumber bahan baku pellet termasuk kaliandra (Hendrati dan Hidayati, 2014). Pelaksanaan studi banding diganti dengan praktek penggunaan pellet. Pergantian metode dipilih karena praktek penggunaan kompor pellet diharapkan mampu menumbuhkan kepercayaan masysrakat Dusun Keceme mengenai sumber energi alternatif terbaharukan. d) Penyiapan bahan dan peralatan

Penyiapan bahan dan peralatan terutama ditujukan untuk penanaman yaitu berupa bahan tanaman (semai) kaliandra, pupuk, ajir, cangkul, tali raffia. Penyiapan bahan berasal dari dua pihak yaitu pihak Prodi Pengelolaan Hutan untuk pembelian bahan dan pihak masyarakat Desa Gerbosari untuk pengadaan bahan yang mudah diperoleh dari sekitar lokasi kegiatan.

e) Penanaman kaliandra

Penanaman kaliandra dilakukan di sela-sela tanaman di lahan milik masyarakat Desa Gerbosari. Pola tanam menyesuaikan lahan dan keinginan petani. Pemanfaata lahan dapat dilakukan dengan penanaman di batas milik. Apabila lahan dibuat terasteras, maka penanaman kaliandra dilakukan di sepanjang teras pada posisi samping teras. Berikut merupakan contoh penanaman pada lahan miring.
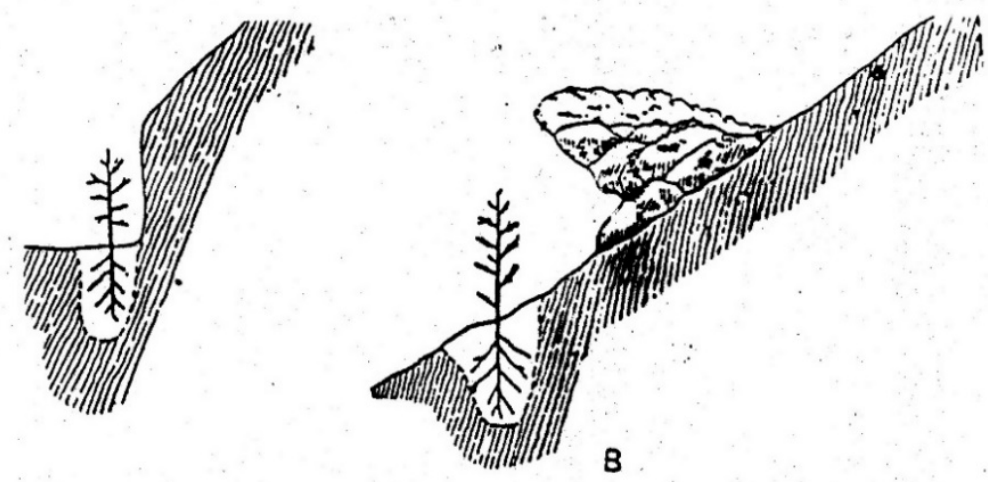

Fig. 132.

A. Plant set in a step-like niche on a steep slope.

$B$. Plant protected by stones on a steep slope. .

Gambar 2. Contoh Penanaman pada Lahan Miring

\section{Metode yang digunakan}

Kegiatan pengabdian ini dilakukan dalam beberapa metode yaitu penyuluhan dan praktek penggunaan alat dan penanaman. Kegiatan pengabdian dilakukan dengan mengundang warga
Dusun Keceme untuk menerima materi yang disampaikan oleh para pembicara. Waktu, lokasi, materi dan pemateri tercantum pada tabel berikut. 
Tabel 2. Lokasi dan Materi Pengabdian Dusun Keceme

\begin{tabular}{|c|c|c|c|c|}
\hline No & Kegiatan & Lokasi & Metode & Pemateri \\
\hline 1 & Sosialisasi Kegiatan & $\begin{array}{l}\text { Dusun } \\
\text { Keceme, } \\
\text { Gerboasri, }\end{array}$ & $\begin{array}{l}\text { Ceramah, Penggalian } \\
\text { informasi melalui } \\
\text { diskusi }\end{array}$ & Eko Prasetyo, M.Sc. \\
\hline 2 & $\begin{array}{l}\text { Penyuluhan kaliandra } \\
\text { sebagai energi } \\
\text { alternatif }\end{array}$ & $\begin{array}{l}\text { Dusun } \\
\text { Keceme, } \\
\text { Gerboasri, }\end{array}$ & $\begin{array}{l}\text { Ceramah dan tanya } \\
\text { jawab }\end{array}$ & $\begin{array}{l}\text { Agus Ngadianto, } \\
\text { M.Sc. }\end{array}$ \\
\hline 3 & $\begin{array}{l}\text { Praktek penggunaan } \\
\text { kompor wood pellet }\end{array}$ & $\begin{array}{l}\text { Dusun } \\
\text { Keceme, } \\
\text { Gerboasri }\end{array}$ & Praktek & Laboran/Teknisi \\
\hline 4 & Penanaman kaliandra & $\begin{array}{l}\text { Dusun } \\
\text { Keceme, } \\
\text { Gerboasri, }\end{array}$ & Praktek & $\begin{array}{l}\text { Prodi, Masyarakat } \\
\text { Dusun Keceme }\end{array}$ \\
\hline
\end{tabular}

HASIL DAN PEMBAHASAN

Kegiatan pengabdian ini dilakukan dalam beberapa tahapan kegiatan. Kegiatan tersebut yaitu sosialisai kegitan, penyuluhan, praktek penggunaan kompor dan penanaman seperti terlihat pada tabel berikut.

Tabel 3. Waktu dan Durasi Kegiatan Pengabdian Masyarakat di Desa Keceme

\begin{tabular}{|c|c|c|c|c|c|}
\hline No & Kegiatan & Lokasi & Tanggal & Peserta & $\begin{array}{c}\text { Durasi } \\
\text { Kegiatan }\end{array}$ \\
\hline 1 & Sosialisasi Kegiatan & $\begin{array}{l}\text { Dusun Keceme, } \\
\text { Gerboasri, }\end{array}$ & $\begin{array}{l}2 \text { September } \\
2016\end{array}$ & $\begin{array}{c}28 \\
\text { orang }\end{array}$ & 6 jam \\
\hline 2 & $\begin{array}{l}\text { Penyuluhan kaliandra } \\
\text { sebagai energi alternatif }\end{array}$ & $\begin{array}{l}\text { Dusun Keceme, } \\
\text { Gerboasri, }\end{array}$ & $\begin{array}{l}27 \text { September } \\
2016\end{array}$ & $\begin{array}{l}25 \\
\text { orang }\end{array}$ & 6 jam \\
\hline 3 & $\begin{array}{l}\text { Praktek penggunaan } \\
\text { kompor wood pellet }\end{array}$ & $\begin{array}{l}\text { Dusun Keceme, } \\
\text { Gerboasri }\end{array}$ & $\begin{array}{l}27 \text { September } \\
2016\end{array}$ & $\begin{array}{l}25 \\
\text { orang }\end{array}$ & 2 jam \\
\hline 4 & Penanaman kaliandra & $\begin{array}{l}\text { Dusun Keceme, } \\
\text { Gerboasri, }\end{array}$ & $\begin{array}{c}7 \text { Oktober } \\
2016\end{array}$ & 12 orang & 6 jam \\
\hline
\end{tabular}

\section{Sosialisasi Kegiatan}

Pelaksanaan sosialisasi kegiatan "Penanaman Kaliandra sebagai Kayu Energi dan Hijauan Makanan Ternak pada Pertanaman Agroforestri di Desa Keceme, Samigaluh Kulon Progo"dilakukan bersamaan dengan program pengabdian dengan judul "Pelatihan Pembuatan Pupuk Organik di Desa Keceme, Samigaluh Kulon
Progo". Susunan acara dalam kegiatan penyuluhan ini adalah sebagai berikut :

- Pembukaan

- Sambutan dari Prodi Pengelolan Hutan yang disampaikan Prasetyo Nugroho, S.Hut., M.Sc.

- Penyuluhan/Penyampaian materi

- Penutup 

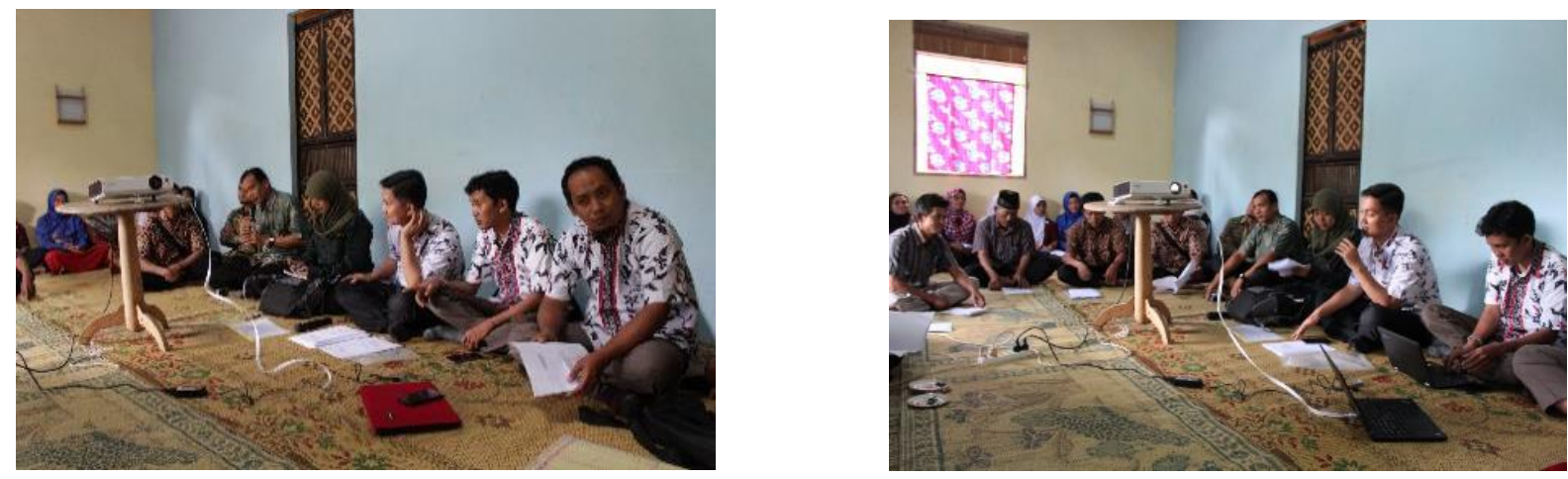

Gambar 3. Sambutan Prodi Pengelolaan Hutan dan Penyuluh Kabupaten Kulon Progo

Sosialisasi mengenai penanaman kaliandra dilakukan dengan metode interaktif yaitu melibatkan peserta sosialisasi untuk berpendapat. Contoh interaksi yang terjalin antara lain dikusi mengenai teknik budidaya yang sudah dikembangkan dan pemanfaatan kaliandra yang sudah dilakukan. Sosialisasi dilakukan dengan tujuan menggali potensi Dusun Keceme terhadap tanaman kaliandra. Kaliandra dimanfaatkan daunnya untuk Hijauan Makanan Ternak (HMT). Ternak yang dikembangkan di Dusun Keceme adalah ternak Kambing Etawa. Rantingranting sisa-sisa makanan ternak dikumpulkan oleh masyarakat untuk

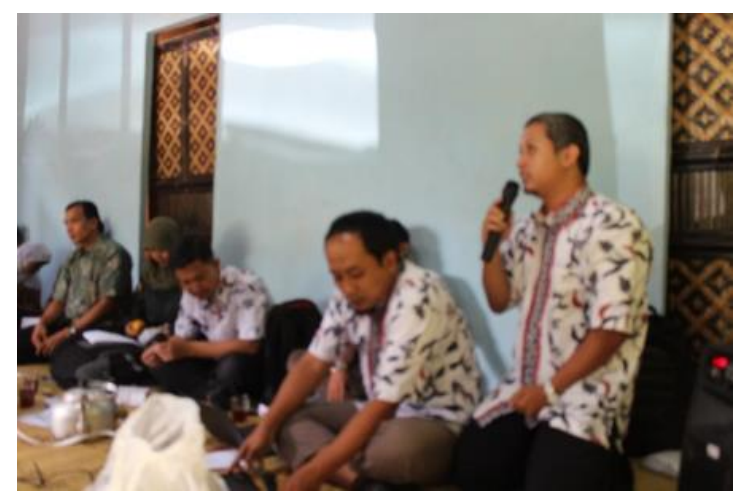

Gambar 4. Pemberian Materi dijadikan kayu bakar baik untuk memenuhi kebutuhan sendiri maupun untuk menambah pendapatan masysrakat dengan cara dijual. Metode ternak yang dikembangkan di Dusun Keceme adalah "cut and carry system" atau sistem merumput. Sistem merumput membuat petani harus menyediakan lahannya untuk ditanami HMT baik berupa rumput atau daun-daun pohon. Sosialisasi dan diskusi dengan masyarakat menghasilkan kesepakatan yaitu program yang dijalankan tidak sebatas penanaman kaliandra, tetapi aspek pemanfaatan kaliandra sebagai kayu energi dan pengenalan wood pellet diperlukan oleh masyarakat Dusun Keceme.

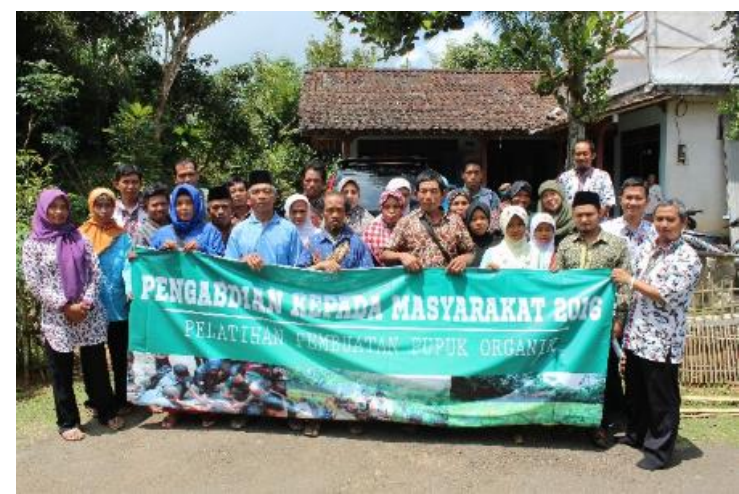

dari segi budidayanya dan penggunaan/pemanfaatan wood pellet secara umum. Kaliandra untuk kayu bakar sudah ditanam di lahan-lahan pribadi dan milik umum di Jawa. Kayunya yang berkerapatan tinggi dengan berat jenis 0,5 - o,8 membuatnya cepat kering dan mudah dibakar, dapat menghasilkan energi yang memenuhi syarat komersial yakni sekitar 46.oo kkal per kg kayu kering dan 7.20o kkal 
panas per kg arang. Untuk produksi kayu bakar, kaliandra biasanya ditanam dengan jarak tanam $1 \times 1 \mathrm{~m}$ atau $1 \times 2 \mathrm{~m}$. Untuk merangsang tunas baru, pohon sebaiknya dipangkas setinggi $30-50 \mathrm{~cm}$ pada akhir musim kemarau, agar pada musim penghujan trubusan sudah mulai muncul. Tanaman kaliandra dapat membentuk trubus dengan cepat setelah dipangkas, dan dengan pemangkasan tiap tahun pada cabang diameter 3-5 cm, tanaman dapat bertahan hidup sampai bertahun-tahun.

Wood pellet dikenalkan kepada masyarakat Dusun Keceme dengan tujuan memberikan informasi mengenai alternatif pemanfaatan kayu kaliandra. Masyarakat Dusun Keceme memanfaatkan ranting dan dahan kaliandra sebagai kayu bakar dan sebagian dijual dengan harga $\mathrm{Rp}$ 10.000,- per ikat bila dijual di Dusun Keceme dan Rp 15.00o,- per ikat bila dijual di Kecamatan Borobudur Magelang. Pengenalan wood pellet dari berbagai bahan baku menarik perhatian masyarakat Keceme. Bahan baku yang dapat digunakan untuk pembuatan wood pellet antara lain sekam padi, serbuk gergaji, daun tebu, kayu mahoni bahkan digunakan limbah uang kertas yang telah dihancurkan. Diskusi mengenai wood pellet didominasi oleh pertanyaan bagaimana proses pembuatan dan proses pengadaan wood pellet untuk masyarakat Keceme. Hal ini menjadi suatu tantangan untuk dapat menyatukan produk hulu yaitu kaliandra dengan produk hilir berupa wood pellet.

\section{Praktek Penggunaan Kompor Pellet}

Kayu merupakan salah satu sumber energi yang diharapkan dapat menggantikan sumber bahan bakar minyak, namun apabila kayu langsung dijadikan sebagai bahan bakar mempunyai sifat-sifat yang kurang menguntungkan, antara lain kadar air yang tinggi, banyak mengeluarkan asap, banyak abu, dan nilai kalornya rendah (Zam dkk, 2009). Analisis SWOT terhadap produk pellet kayu menurut (Sylviani dan Suryandari, 2013) adalah keunggulan produk pelet kayu lainnya adalah mudah dalam pengepakan dan pengangkutan. Peluang permintaan pelet kayu ini dimungkinkan karena bahan bakar yang tidak terbarukan (minyak tanah,gas) saat ini harganya terus meningkat dan terkadang sulit didapat di pasar. Kelemahan dari pelet kayu adalah belum dikenal oleh masyarakat khususnya para Industri Kecil Menegah (IKM). Sementara itu dari pelet kayu adalah dari sisi harga harus bersaing dengan bahan bakar yang tidak terbarukan.

$$
\text { Penggunaan kompor pellet }
$$

dikenalkan kepada masyarakat dengan harapan memberikan informasi dan pengetahuan peluang penghematan bahan bakar dengan menggubakan pellet kayu. Pelet kayu $5 \mathrm{~kg}$ pellet setara dengan $3 \mathrm{~kg}$ gas ("tabung melon"), sedangkan harga pellet kayu sekitar Rp 2.000,- per kg. Kompor pellet diharapkan mampu mensubstitusi ketergantungan masyarakat Keceme terhadap energi fosil (minyak dan gas) dan beralih menjadi masyarakat mandiri energi. Pengenalan kompor yang bersifat percontohan dan percobaan tidak menurunkan antusias masyarakat Keceme untuk menggunakan dan mencoba menggunakan kompor pellet. Hasil praktek kompor pellet menghasilkan panas yang merata dan tahan lama, tetapi mempunyai kelemahan dalam mematikan kompor karena akan menghasilkan banyak asap. Penggunaan pellet memerlukan pemantik berupa kertas atau minyak tanah untuk memulai dan menstimulasi terbakarnya pellet. 

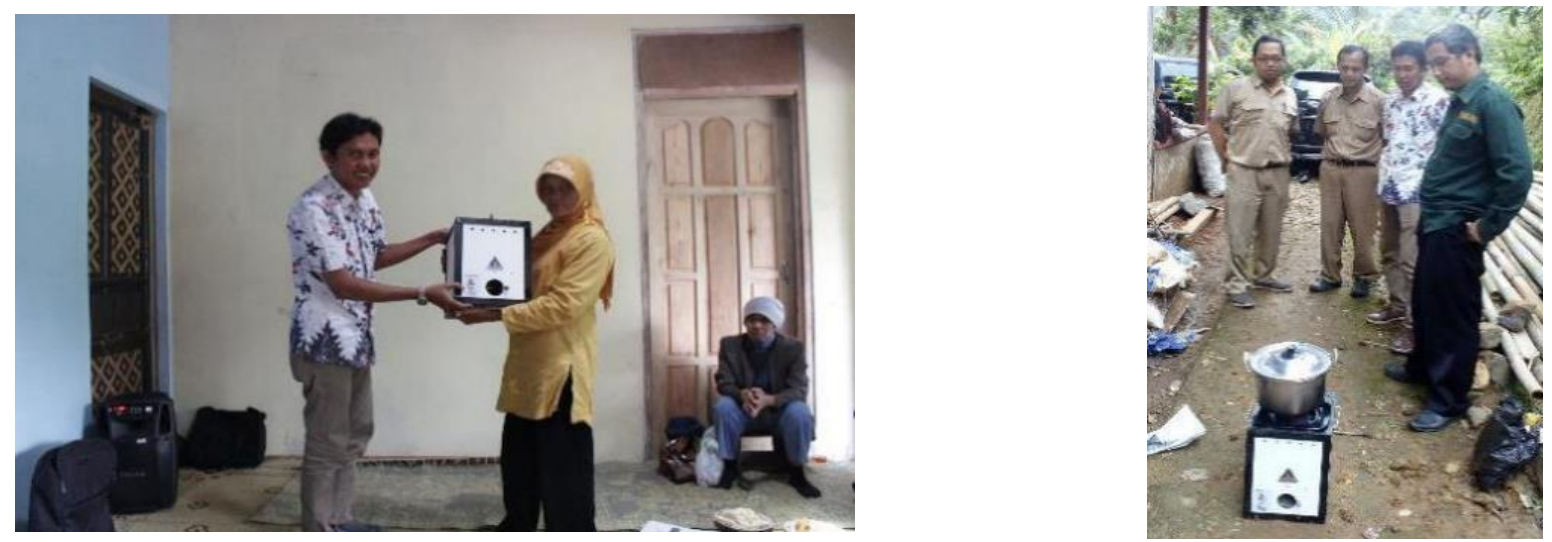

Gambar 5. Penyerahan dan Praktek Penggunaan Kompor Pellet

\section{Penanaman Kaliandra}

Penanaman kaliandra dilakukan pada tanggal 7 Oktober 2016. Budidaya kaliandra menjadi kebutuhan warga Dusun Keceme terutama kebutuhan Hijauan Makanan Ternak. Pertanaman kaliandra sudah sejak lama dilakukan masyarakat Keceme. Budidaya kambing etawa menyebabkan masyarakat Keceme menanam kaliandra sebagai Hijauan Makanan Ternak. Pola tanam yang ada di dusun ini adalah pola agroforestri. Tanaman kaliandra ditanam di tepi-tepi teras pada lahan. Terasiring diterapkan pada lahan masyarakat Keceme karena topografi di lokasi tersebut relatif curam. Metode ini termasuk dalam pola agroforestry alley cropping. Alley cropping adalah penanaman larikan pohon dengan tujuan memberi ruang (berbentuk lorong) untuk tanmanan pertanian maupun holtikultura (USDA, 2017). Pola ini diharapkan mampu memberikan hasil yang optimal dengan keterbatasan lahan yang

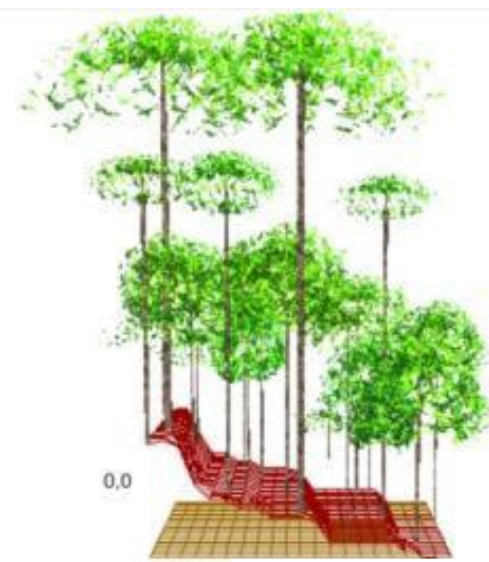

ada. Pola ini dapat memperbaiki pola yang sudah diterapkan masyawakat yaitu pola random mixture. Tipologi agroforestri hutan rakyat di Desa Gerbosari (termasuk Dusun Keceme) berbentuk random mixture, yaitu pertanaman acak dengan kombinasi berbagai jenis tanaman kayu di suatu unit lahan dengan jarak tanam dan struktur yang kompleks (Utomo et al.,2013). Program penyuluhan dan penanaman kaliandra memberikan perspektif baru mengenai pola tanam yang lebih terencana dan tidak acak. Selain kaliandra jenis yang banyak ditemui di Dusun Keceme antara lain sengon, cengkeh, mahoni, nangka, kopi dan petai. Tanaman herbal berupa kapulaga banyak ditemukan di sela-sela teras pada lahan. dan Penanaman Kaliandra

Penanaman kaliandara dilakukan bersama antara Prodi Pengelolaan Hutan Sekolah Vokasi UGM, Kelompok Tani Sedyo Rukun, Kepala Dusun Keceme dan warga masyarakat. Penanaman kaliandra yang

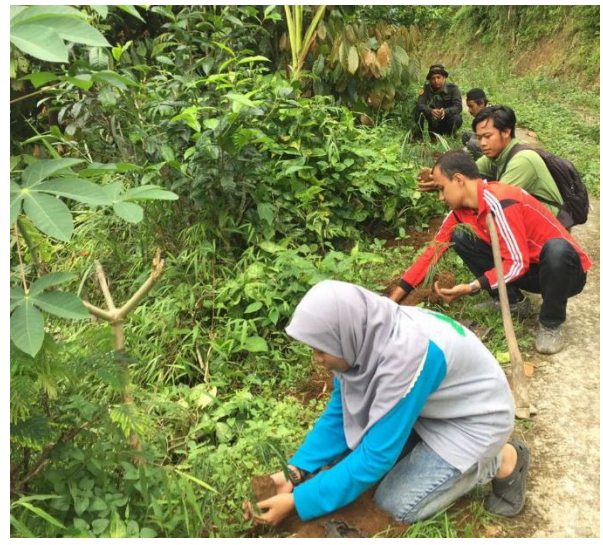

Gambar 6. Pola Agroforestri (Utomo, 2012) 
sudah sejak lampau menjadikan masyarakat sudah terbiasa dan tidak mengalami masalah dalam pembudidayaan kaliandra. Penanaman kaliandra sudah merupakan kebutuhan masyarakat keceme sehingga penanaman pada program pengabdian ini bersifat simbolis.

\section{SIMPULAN}

1. Program Pengabdian Masyarakat dengan judul "Penanaman Kaliandra sebagai Kayu Energi dan Hijauan Makanan Ternak pada Pertanaman Agroforestri Masyarakat Desa Gerbosari Samigaluh Kulon Progo" mampu memberikan pemahaman awal kepada masyarakat Dusun Keceme mengenai manfaat kaliandra sebagai alternatif energi terbarukan yaitu dalam bentuk pellet kayu.

2. Program pengabdian memberikan pembaruan mengenai teknik penanaman agroforestri kaliandra yang sudah lama dipraktekkan masyarakat Dusun Keceme yaitu pola random mixture (acak) dengan pola yang lebih terencana yaitu penanaman di tepi-tepi teras lahan.

\section{DAFTAR PUSTAKA}

Badan Pusat Statistik Kabupaten Kulon Progo. (2011). Kulon Progo dalam Angka. Badan Pusat Statistik Republik Indonesia

Hendrati,R.L dan Hidayati,N. (2014). Budidaya Kaliandra (Calliandra calothyrsus) untuk Bahan Baku Sumber Energi. IPB Press. Bogor

Sylviani dan E.Y. Suryandari. (2013). Potensi Pengembangan Industri Pelet Kayu sebagai Bahan Bakar Terbarukan, Studi Kasus di Kabupaten Wonosobo. Jurnal Penelitian Sosial dan Ekonomi Kehutanan Vol 10, No 4.Hal 235-246.

USDA. (2017). Alley Cropping: An Agroforestry Practice. Agroforestry Note\#12. USDA National Agroforestry Center.

Utomo, S., P. Nugroho, Budiadi.2013. Kapasitas Infiltrasi Tanah pada
Berbagai Karakter Agroforestri Kapulaga di Desa Gerbosari ,Kecamatan Samigaluh, Kabupaten Kulon Progo. Proseding Seminar Nasional Agroforestry "Agroforestri untuk Pangan dan Lingkungan Lebih Baik". Universitas Brawijaya. Malang. Hal: 270-275

Utomo, S. (2012). Kajian Biofisik Agroforestri Kapulaga (Amomum cardomomum Willd.) di Hutan Rakyat Pegunungan Menoreh Kabupaten Kulon Progo D.I.Yogyakarta. Tesis. Program Studi Ilmu Kehutanan. Fakultas Kehutanan. Universitas Gadjah Mada. (tidak dipublikasikan)

Zam HA, Syahidah, dan B. Putranto. (2009). Karakteristik Pellet Kayu Gmelina (Roxb.) Fakultas Kehutanan Universitas Hasanudin Makassar. 
